\title{
ESTIMASI LAJU ALIRAN SIRKULASI ALAM BERDASARKAN BEDA TEMPERATUR PADA UNTAI FASSIP-01
}

\author{
Almadesya Rinaldi ${ }^{1}$, Lovini Gabriella ${ }^{1}$, Giarno $^{2}$, Joko Prasetio ${ }^{2}$, Mulya Juarsa ${ }^{2}$ ** \\ ${ }^{1}$ Mahasiswa Departemen Fisika, FMIPA Universitas Padjadjaran, Bandung \\ Kampus UNPAD, Jatinangor, Sumedang 45363 \\ ${ }^{2}$ Pusat Teknologi dan Keselamatan Reaktor Nuklir Badan Tenaga Nuklir Nasional \\ Gedung 80 Kawasan PUSPIPTEK, Setu, Tangerang Selatan 15310 \\ *email: juars@batan.go.id
}

\begin{abstract}
ABSTRAK
ESTIMASI LAJU ALIRAN SIRKULASI ALAM BERDASARKAN BEDA TEMPERATUR PADA UNTAI FASSIP-01. Penguasaan terhadap kapasitas pendinginan system pendinging pasif dilakukan melalui penelitian di laboratorium Termohidrolika PTKRN BATAN. Untai FASSIP-01 telah dikonstruksi untuk studi fenomena sirkulasi alam. Tujuan penelitian adalah untuk mengestimasi laju aliran sirkulasi alam berdasarkan beda temperatur di bagian heater $(\mathrm{BCH}$, blanket ceramic heater) dan di bagian cooler atau WCT (water cooling tank). Metode penelitian dilakukan dengan menentukan perubahan di WCT untuk variasi temperature $10^{\circ} \mathrm{C}, 20^{\circ} \mathrm{C}, 30^{\circ} \mathrm{C}, 40^{\circ} \mathrm{C}$ dan $50^{\circ} \mathrm{C}$, serta perubahan temperature di $\mathrm{BCH}$ yaitu $60^{\circ} \mathrm{C}, 70^{\circ} \mathrm{C}, 80^{\circ} \mathrm{C}, 90^{\circ} \mathrm{C}$ dan $100^{\circ} \mathrm{C}$. Parameter geometri Untai FASSIP-01 seperti tinggi untai $600 \mathrm{~cm}$, lebar untai $350 \mathrm{~cm}$ dan diameter pipa sebesar 2,56 cm dimasukkan dalam perhitungan. Hasil perhitungan menunjukkan bahwa semakin besar perbedaan temperatur anatara $\mathrm{BCH}$ dan WTC, maka akan semakin besar pula laju aliran air pada untai FASSIP-01. Ketika perbedaan temperatur $\mathrm{BCH}$ dan $\mathrm{WTC} 10^{\circ} \mathrm{C}$, laju aliran bernilai paling kecil yaitu $0,2903 \mathrm{~m} / \mathrm{s}$, sedangkan ketika perbedaan temperatur $\mathrm{BCH}$ dan $\mathrm{WTC} 90^{\circ} \mathrm{C}$, laju aliran bernilai paling besar yaitu 1,0456 $\mathrm{m} / \mathrm{s}$.
\end{abstract}

Kata Kunci : laju aliran, sirkulasi alami, BCH dan WCT, temperatur, untai FASSIP-01

\section{ABSTRACT}

ESTIMATION OF NATURAL CIRCULATION FLOW RATE BASED ON DIFFERENT TEMPERATURE IN FASSIP-01. Mastery of the cooling capacity of the passive pendinging system is carried out through research in the PTKRN BATAN Thermal Hydraulics laboratory. FASSIP-01 Loop has been constructed to study on natural circulation phenomena. The purpose of this research is to estimate the flow rate of natural circulation based on the differences of temperature in the heater (BCH, blanket ceramic heater) and in the cooler or WCT (water cooling tank). The research method was carried out by determining changes in WCT for variations in temperature of $10^{\circ} \mathrm{C}, 20^{\circ} \mathrm{C}, 30^{\circ} \mathrm{C}, 40^{\circ} \mathrm{C}$ and $50{ }^{\circ} \mathrm{C}$, and changes in temperature in $\mathrm{BCH}$ of $60^{\circ} \mathrm{C}, 70^{\circ} \mathrm{C}, 80^{\circ} \mathrm{C}, 90^{\circ} \mathrm{C}$ and $100{ }^{\circ} \mathrm{C}$. The geometrical parameter of FASSIP-01 Loop such as the height of the loop is $600 \mathrm{~cm}$, the width of the loop is $350 \mathrm{~cm}$ and the diameter of pipe is $2.56 \mathrm{~cm}$ were included in the calculation. The calculation results show that the greater the temperature difference between $B C H$ and WTC, the greater the flow rate of water in the FASSIP-01 strand. When the difference in temperature of $B C H$ and $W T C$ is $10^{\circ} \mathrm{C}$, the flow rate has the smallest value of $0.2903 \mathrm{~m} / \mathrm{s}$, whereas when the difference in temperature of $\mathrm{BCH}$ and $W T C$ is $90^{\circ} \mathrm{C}$, the flow rate is greatest at $1.0456 \mathrm{~m} / \mathrm{s}$.

Keywords : flow rate, natural circulation, BCH and WCT, temperature, FASSIP-01 test loop. 


\section{PENDAHULUAN}

PLTN adalah pembangkit listrik yang menggunakan tenaga reaksi fisi inti dari unsur radioaktif yang dapat menghasilkan uap panas untuk memutar turbin pembangkit listrik. Sayangnya, di Indonesia belum berdiri PLTN dikarenakan adanya rasa takut terhadap bencana jika pembangkit nuklir mengalami kebocoran. Efek radiasi reaktor nuklir ditakutkan bisa menimbulkan efek terhadap berbagai masalah kesehatan, salah satunya adalah kanker. Banyak peristiwa dalam sejarah yang menuliskan bahwa kebocoran reaktor nuklir membuat penderitaan berkepanjangan bagi masyarakat di lokasi tersebut. Tragedi terakhir adalah bocornya reaktor nuklir di Fukushima, Jepang. Kebocoran reaktor ini merupakan bencana nuklir terburuk dan berakibat air radioaktif mengalir ke laut yang berdampak dengan kemungkinan terkontaminasinya air laut ${ }^{[1]}$.

Berdasarkan dari kecelakaan yang pernah terjadi, maka dibutuhkan suatu sistem keselamatan yang dapat menyelamatkan reaktor dari kecelakaan kebocoran reaktor akibat sistem pendingin yang gagal fungsi. Sistem pendingin yang gagal fungsi tersebut adalah sistem pendingin aktif yang kehilangan daya akibat listrik padam sehingga menyebabkan pompa sirkulasi tidak bekerja.
Sistem keselamatan yang sedang banyak dibahas sekarang ini adalah sistem pendingin pasif yang tidak membutuhkan energi dari luar. Sebagai bandingan pada sistem pendingin aktif, sistem tidak dapat berkerja pada saat listrik padam sehingga ketika terjadi kecelakaan yang serius.Sebaliknya, sistem pendingin pasif akan selalu bekerja dengan memanfaatkan panas dari reaktor dan tidak membutuhkan energi listrik seperti sistem pendingin aktif.

Penelitian sistem pendingin pasif untuk mempelajari fenomena sirkulasi alam menjadi penelitian yag penting dalam pengembangan manajemen keselamatan reaktor nuklir. Sehingga, PTKRN-BATAN (Pusat Teknologi dan Keselamatan Reaktor Nuklir Badan Tenaga Nuklir Nasional) telah membangun Untai FASSIP-01 (Fasilitas Simulasi Sistem Pasif-01). Dimana, sistem pendingin ini dapat bersirkulasi tanpa menggunakan energi luar (natural circulation). Sistem ini menggunakan prinsip perbedaan densitas air akibat perbedaan temperatur antara tangki panas dan tangki dingin. Pergerakan air pada untai FASSIP-01 terjadi akibat gaya apung dan gaya gravitasi yang terjadi pada air ${ }^{[2]}$. Pada simulasi FASSIP-01 ini, panas yang dihasilkan reaktor nuklir diganti dengan pemanas tahanan termal yang mengggunakan prinsip hukum Joule, dimana kawat yang dibentuk lilitan ketika diberi energi listrik akan menghasilkan tumbukan 
antar elektron ${ }^{[3]}$. Pemanas digunakan untuk memanaskan air yang melewati pipa, dan air akan bersirkulasi serta kalor akan dibuang saat melewati tangki pendingin. Dalam penelitian ini dilakukan estimasi laju aliran sirkulasi alam berdasarkan perbedaan temperatur menggunakan program Matlab pada Untai FASSIP-01 berdasarkan data desain dan simulasi variasi temperatur di tangki pemanas dan tangki pendingin

\section{TEORI}

Sistem keselamatan PLTN (pembangkit listrik tenaga nuklir) berbasis system pendingin aktif membutuhkan sumber daya eksternal, seperti mesin diesel darurat, untuk mempertahankan operasinya, sementara sistem keselamatan pasif bergantung pada gaya bawaannya, seperti tekanan gas terkompresi atau gravitasi dari berbagai cairan ${ }^{[4]}$. Sistem pasif pada eksperimen ini menggunakan konsep sirkulasi fluida dalam lingkaran tanpa gaya eksternal atau intervensi eksternal. Jenis sirkulasi fluida ini dikenal sebagai sirkulasi alam, yang dapat terjadi karena gaya bouyancy dan gaya gravitasi. Kedua gaya ini diciptakan oleh perubahan densitas fluida di daerah panas dan di daerah dingin. Mekanisme pemindahan panas pasif ini dapat diimplementasikan di kondisi operasi normal dan dalam kondisi kecelakaan ${ }^{[5]}$. Untai FASSIP 01 terdapat komponen WCT (water cooling tank) di bagian atas dan $\mathrm{BCH}$ (blanket ceramic heater) di bagian bawah. Bagian WCT adalah tangki pendingin yang menghasilkan fluida dengan densitas besar dan akan turun akibat gaya gravitasi karena posisinya lebih tinggi. Sedangkan $\mathrm{BCH}$ adalah bagian pemanas yang akan menghasilkan fluida dengan densitas rendah dan akan naik akibat gaya bouyancy. Untai FASSIP-01 berbentuk untai rectangular yang tersusun dari rangkaian pipa (section pipe) yang terkoneksi satu sama lainnya.

Perhitungan laju aliran sirkulai alam pada Untai FASSIP-01 (terlihat pada Gambar 1) melibatkan parameter viskositas dinamis, panjang total loop, perbedaan tinggi antara $\mathrm{BCH}$ dan WCT, loss coefficient, densitas fluida ketika dalam keadaan panas maupun dingin, dan diameter pipa yang dilewati. Viskositas dinamis air, dan densitas fluida diperoleh studi literatur. Panjang total loop yakni seluruh aliran yang dilewati fluida baik pipa SS304, tangki pemanas dan tangki pendingin. Perbedaan tinggi antara tangki pemanas dan pendingin. Loss coefficient $(\mathrm{K})$ dan diameter pipa diperoleh dari struktur geometri pemipaan desain Untai FASSIP-01. Laju aliran dapat didefinisikan dengan persamaan berikut ${ }^{[5]}$.

$$
v=\frac{-64 \mu L+\sqrt{(64 \mu L)^{2}+8 g H K \overline{\rho_{w}} D^{4}\left(\rho_{C}-\rho_{H}\right)}}{2 K \overline{\rho_{w}} D^{2}}
$$

Berdasarkan persamaan (1), parameter geometri terdiri dari L (panjang total pipa), 
D (diameter pipe), H (beda ketinggian bagian cooler dan heater)

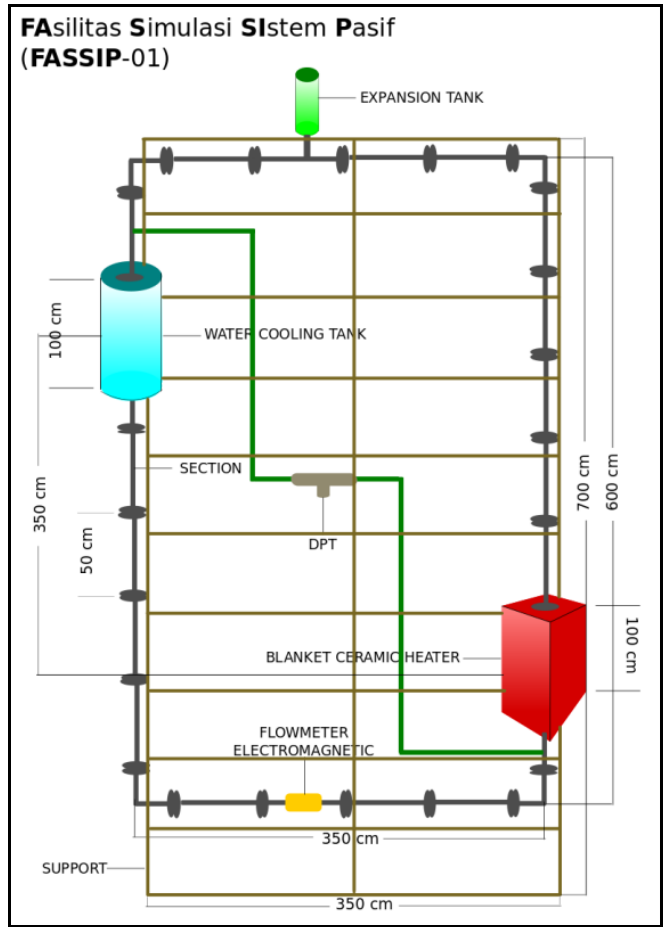

Gambar 1. Untai FASSIP-01

Berdasarkan Gambar 1, uraian dari komponen utama dan komponen Untai FASSIP-01 sebagai fasilitas uji untuk manajemen keselamatan PLTN ${ }^{[6]}$ dijelaskan, sebagai berikut:

- Komponen Utama

1. Section merupakan pipa aliran yang berfungsi menjadi perantara antara satu komponen dengan komponen lainnya. Section adalah komponen yang berbahan dasar baja Stainless Steel SS304. Pada masing-masing section dipasang alat ukur temperatur (thermocouple) untuk kemudian dicatat laju aliran perpindahan yang terjadi disepanjang section. Gambar 2.a adalah penampang dari komponen section lurus dan Gambar 2.b. merupaka pipa belokan dengan bend $90^{\circ}$ untuk tiap sudut yang digunakan pada rectangular loop FASSIP-01 (terdapat 4 bend).

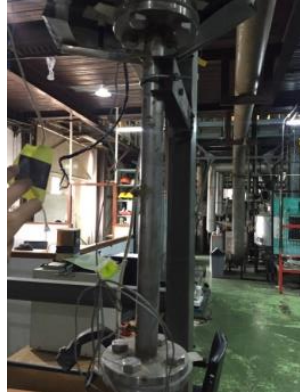

(a)

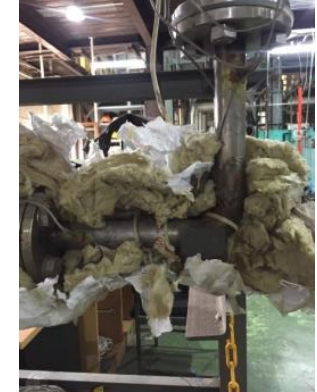

(b)
Gambar 2. (a) Section Lurus; (b) Section Bend $90^{\circ}$

2. Rectangular Loop (Untai Rektangular) ditunjukkan pada Gambar 3, merupakan untaian yang terbentuk dari sambungan antar section dan komponen yang bersambung. Rectangular loop adalah untai berbentuk persegi panjang, sehingga memungkinkan arus akan terus bersirkulasi secara kontinyu tanpa terhambat sesuatu.

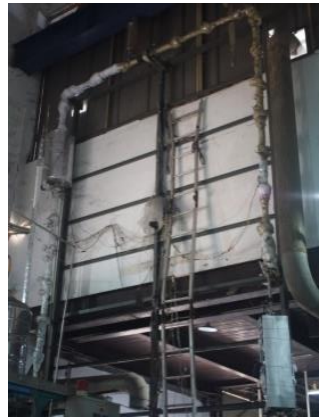

Gambar 3. Rectangular Loop

3. Blanket ceramic heater (Gambar 4) adalah suatu bagian panas yang diasumsikan sebagai sumber kalor dari reaktor atau tempat terjadinya 
pembangkitan kalor yang pada akhirnya nanti digunakan sebagai energi panas yang mampu dikonversikan menjadi berbagai energi lainnya. Blanket ceramic heater pada dasarnya adalah sebuah tangki berbentuk balok dan di dalamnya terdapat keramik yang mengelilingi pipa SS304 yang dialiri fluida, sehingga ketika keramik memancarkan radiasi kalor (panas), fluida di dalam pipa juga langsung mengalami kenaikan temperatur.

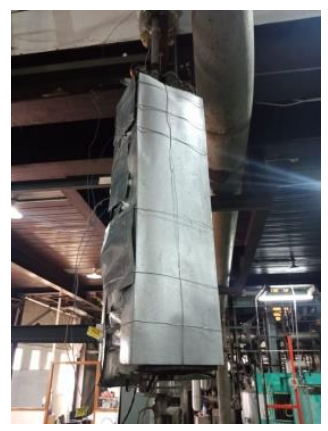

\section{Gambar 4. Blanket Ceramic Heater}

4. Water Cooling Tank berfungsi layaknya sebagai bagian pendingin reaktor yang bekerja melepaskan kalor ke lingkungan (Gambar 5). Tangki cooler menggunakan bantuan refrigerator sebagai piranti pendingin. Dengan support refrigerant R22 dan tenaga refrigerator mencapai $2 \mathrm{PK}$, estimasi refrigerator $2 \mathrm{PK}$ akan mengalami shut ketika mencapai 10 jam masa pengoperasian karena tidak mampu mensupport proses pelepasan kalor secara terus menerus. Di sisi lain, karena eksperimen berlangsung \pm 5 jam, maka refrigerator tidak terdeteksi bermasalah dengan shutnya.

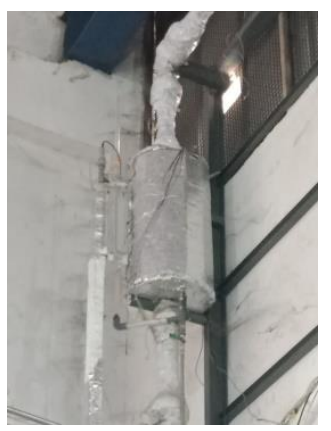

\section{Gambar 5. Water Cooling Tank}

5. Expansion Tank adalah sebuah tangki medium yang nantinya berfungsi sebagai tangki kompensasi tekanan yang akan mengekspansi atau membuang sisa fluida yang melebihi batas normal. Jadi, jiika tekanan pada aliran loop berlebih dan bersifat cenderung fluktif, maka tangki ekspansi akan bertindak sebagai kompensator.

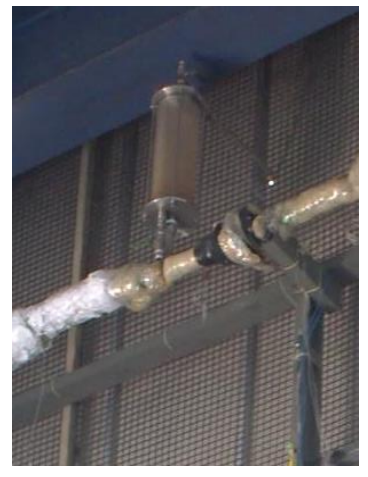

\section{Gambar 1. Expansion Tank}

6. Support adalah besi rigid berbentuk persegi panjang yang berfungsi sebagai penyangga dari rectangular loop dan perangkat dari FASSIP-01. Jadi, susunan FASSIP-01 yang terdiri dari komponen utama dan pendukung serta alat ukur akan terpasang pada support 
yang terbuat dari campuran besi dan karbon.

\section{- Komponen Pendukung dan Alat Ukur}

1. Heater yang digunakan adalah jenis ceramic brick yang di dalamnya terdapat open coil heater. Ceramic heater ini akan memanaskan pipa rectangular loop dengan cara radiasi, sehingga air di dalam pipa akan ikut panas dan naik ke atas.

2. Refrigerator (mesin pendingin) adalah piranti supplyer energi berbentuk pendingin yang dipergunakan untuk menurunkan temperatur fluida ketika mengalir di WCT. Refrigerator (yang di dalamnya terdapat R22) disambungkan dengan Water Cooling Tank melalui lubang inlet dan outlet yang terdapat pada tank tersebut.

3. Thermocouple adalah alat ukur yang dikhususkan untuk mengukur temperatur di sebuah kondisi yang terhubung dengan piranti elektronik. Thermocouple yang digunakan adalah tipe $\mathrm{K}$, dan ditempelkan dengan perekat khusus di tiap-tiap komponen yang dirasa perlu dilakukan pembacaan temperatur.

4. Differential Pressure Transmitter (DPT) berfungsi sebagai komponen yang digunakan untuk mengatur beda tekanan pada WCT maupun BCH.
5. Flowmeter yang digunakan adalah flowmeter elektromagnetik yang sudah diinstal secara horizontal pada rectangular loop bagian bawah, fungsinya adalah untuk mendeteksi aliran yang mengalir di seluruh rangkaian untai FASSIP-01.

\section{METODE PENELITIAN}

Fenomena sirkulasi alam ini lebih mengarah ke masalah hidrolik daripada masalah perpindahan panas, meskipun hasil sirkulasi alam menghilangkan panas dari sumber dan mengangkutnya ke heat sink dan hal ini merupakan yang paling penting dalam keselamatan reaktor ${ }^{[7]}$

Proses perhitungan untuk estimasi laju aliran fluida pada desain Untai FASSIP01dilakukan berdasarkan diagram alir seperti yang ditunjukkan pada Gambar 7.

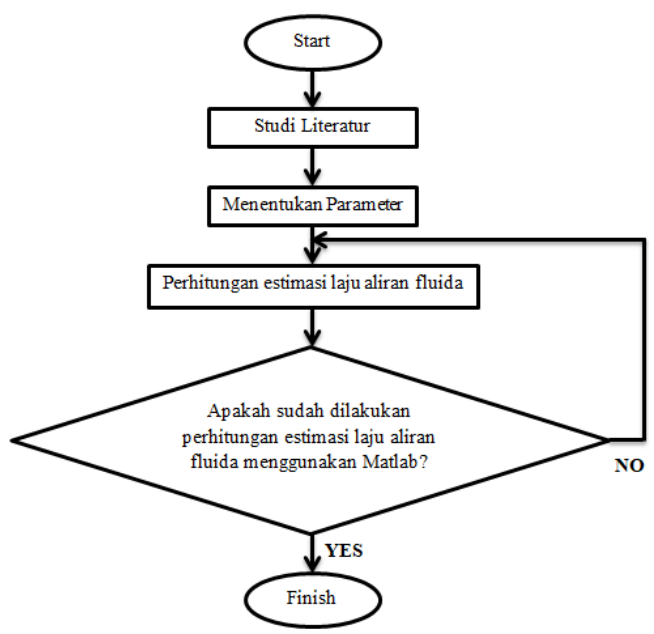

Gambar 7. Diagram alir perhitungan estimasi laju aliran sirkulasi alam

Untuk mempermudah perhitungan digunakan program komputasi berbasis 
Matlab dengan script program seperti yang ditunjukkan pada Gambar 8.

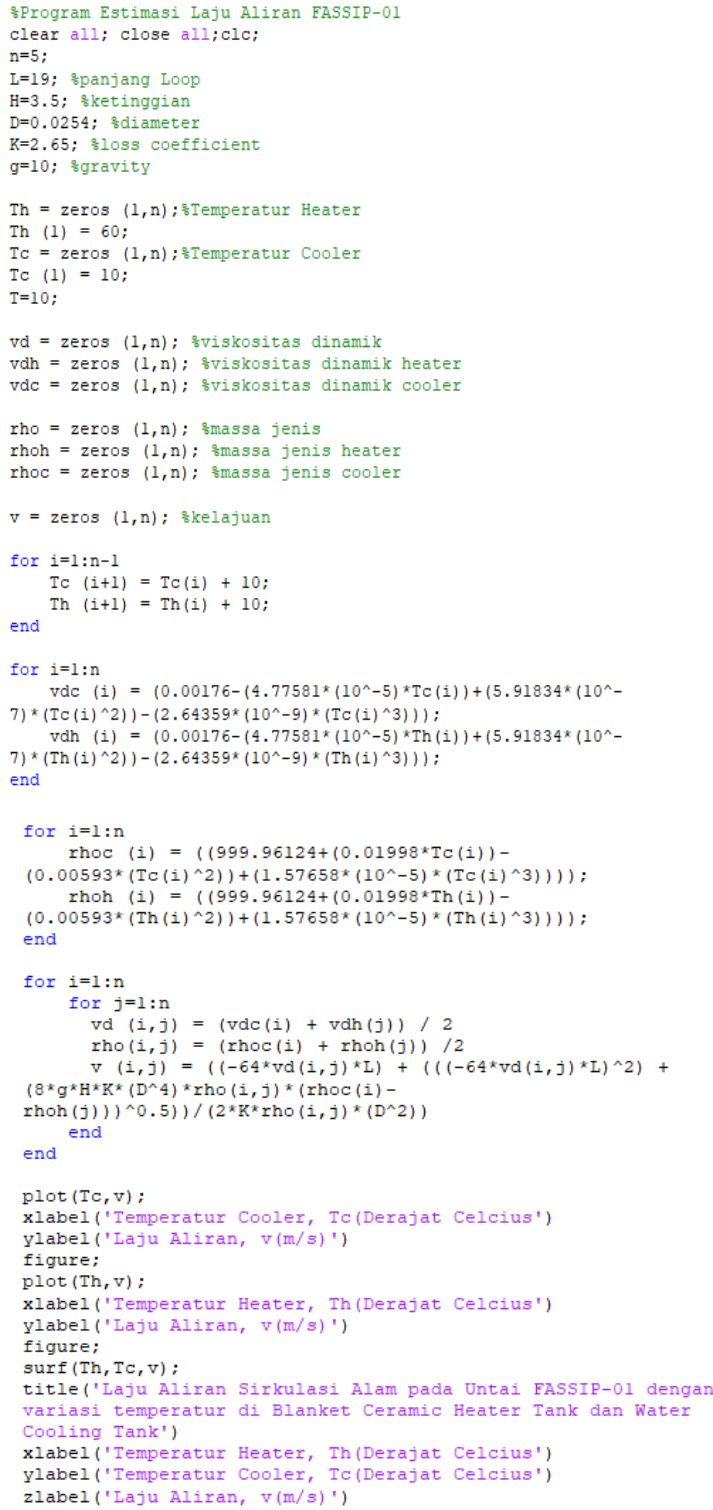

Gambar 8. Script Matlab perhitungan laju aliran sirkulasi alam untai FASSIP-01

Variasi temperatur tangki pendingin yang digunakan untuk perhitungan laju aliran sirkulasi alam yaitu $10^{\circ} \mathrm{C}, 20^{\circ} \mathrm{C}, 30^{\circ} \mathrm{C}$, $40^{\circ} \mathrm{C}, \quad 40^{\circ} \mathrm{C}, 50^{\circ} \mathrm{C}$ dan variasi temperatur tangki pemanas yang digunakan yaitu $60^{\circ} \mathrm{C}$, $70^{\circ} \mathrm{C}, 80^{\circ} \mathrm{C}, 90^{\circ} \mathrm{C}, 100^{\circ} \mathrm{C}$.

\section{HASIL DAN PEMBAHASAN}

Perhitungan Estimasi Laju Aliran Fluida (Menggunakan Matlab)

Laju aliran fluida dipengaruhi oleh geometri parameter yaitu panjang total loop $(L)$, perbedaan ketinggian tabung tangki pemanas dan tabung tangki pendingin $(H)$, diameter pipa aliran (D), dan thermal hidrolik parameter yaitu temperature $(T)$.

1. Panjang lotal loop $(\boldsymbol{L})$ terdiri dari pipa yang dilewati aliran fluida, yaitu pipa SS304 flange 1 inch sepanjang $19 \mathrm{~m}$

2. Perbedaan ketinggian $(\boldsymbol{H})$ yaitu jarak antara tabung tangki heater dan tabung tangki cooler, yaitu sebesar 3,5 m.

3. Diameter Pipa $(\boldsymbol{D})$ yang digunakan pada Untai FASSIP-01 yaitu pipa SS304 dan flange berukuran 1 inch $(2,54 \mathrm{~cm})$.

4. Viskositas dinamik air ( $\boldsymbol{\mu})$ berubah-ubah terhadap temperatur, untuk mendapatkan viskositas dinamik air dengan menggunakan formulasi sifat fisik air ${ }^{[9]}$, didapat persamaan sebagai berikut .

$$
\begin{aligned}
\mu(T)= & 0,00176-\left(4,77581 \times\left(10^{-5}\right) T\right)+ \\
& \left(5,91834 \times\left(10^{-7}\right) T^{2}\right)-(2,64359 \times \\
& \left.\left(10^{-9}\right) T^{3}\right)
\end{aligned}
$$

$T=$ temperature $\left({ }^{\circ} \mathrm{C}\right)$

$\mu=\operatorname{viskositas}$ dinamik (Pa.s)

Dari fungsi diatas maka dapat dilakukan perhitungan, viskositas dinamik air sebagai berikut. 


$$
\begin{aligned}
& \boldsymbol{T}_{\boldsymbol{C}}=10^{\circ} \mathrm{C} \text {, } \\
& \mu(10)=0,00176-(4,77581 \times(10 \\
& \left.\left.{ }^{5}\right) 10\right)+\left(5,91834 \times\left(10^{-7}\right) 10^{2}\right)- \\
& \left(2,64359 \times\left(10^{-9}\right) 10^{3}\right) \\
& =0,001339 \mathrm{~Pa} . \mathrm{s} \\
& \mu(60)=0,00176-\left(4,77581 \quad \mathrm{x} \quad\left(10^{-}\right.\right. \\
& \left.\left.{ }^{5}\right) 60\right)+\left(5,91834 \quad \text { x }\left(10^{-7}\right) 60^{2}\right)- \\
& \left(2,64359 \times\left(10^{-9}\right) 60^{3}\right) \\
& =0,000454 \text { Pa.s }
\end{aligned}
$$

Viskositas dinamik air adalah hasil bagi dua antara penjumlahan viskositas dinamik air pada temperatur cooler dan pada temperatur heater.

$\mu=\frac{\mu(10)+\mu(60)}{2}=0,000897$ Pa.s

Untuk temperatur yang lain dapat dilakukan perhitungan yang sama seperti diatas.

5. Loss Coeficient (K) Untai FASSIP 02 terdapat pada beberapa seperti yang ditampilkan pada Tabel 1.

Tabel 1. Nilai Loss Coefficient

\begin{tabular}{|c|l|c|c|}
\hline No & \multicolumn{1}{|c|}{ Tipe } & Simbol & $\mathrm{K}$ \\
\hline 1. & $\begin{array}{l}\text { Tees Line } \\
\text { flow,flanged }\end{array}$ & $\mathrm{K} 1$ & 0.2 \\
\hline 2. & $\begin{array}{l}\text { Elbow Regular } \\
90^{\circ}, \text { flanged }\end{array}$ & $\mathrm{K} 2$ & 0.3 \\
\hline 3. & $\begin{array}{l}\text { Slightly } \\
\text { Rounded Inlet }\end{array}$ & $\mathrm{K} 3$ & 0.25 \\
\hline 4. & $\begin{array}{l}\text { Slightly } \\
\text { Rounded Outlet }\end{array}$ & $\mathrm{K} 4$ & 1.00 \\
\hline
\end{tabular}

Setelah mendapatkan data Loss coefficient (K), selanjutkan dilakukan perhitungan Sehingga diperoleh nilai densitas sebagai berikut:

$$
\begin{aligned}
& \mathrm{K}=\mathrm{K} 1 \times 1+\mathrm{K} 2 \times 4+\mathrm{K} 3 \times 1+\mathrm{K} 4 \times 1 \\
& \mathrm{~K}=0,2 \times 1+0,3 \times 4+0,25 \times 1+1,00 \times 1 \\
& \mathrm{~K}=2,65
\end{aligned}
$$

6. Densitas air akan mengikuti perubahan temperatur dari pemanas hingga pendinginan $^{[9]}$. Jika densitas air rendah maka akan terjadi gaya bouyancy dan jika densitas air besar maka akan terjadi gaya gravitasi. Untuk mendapatkan kerapatan air dengan menggunakan formulasi sifat fisik air ${ }^{[10]}$, yang ditunjukkan pada persamaan (3)

$\rho(T)=999,96124+(0,01998 T)-$

$\left(0,00593 T^{2}\right)+\left(1,57658 x\left(10^{-5}\right) T^{3}\right)$

Untuk temperature setting di bagian pendingin dari $10^{\circ} \mathrm{C}$ dan di bagian pemanas $60^{\circ} \mathrm{C}$, diperoleh model perhitungan densitas air fungsi temperatur dapat dihitung sebagai berikut $\therefore$

$$
\begin{aligned}
& \boldsymbol{T}_{\boldsymbol{C}}=10^{\circ} \mathrm{C} \\
& \rho(10)=999,96124+(0,01998(10))- \\
& \left(0,00593\left(10^{2}\right)\right)+\left(1,57658 \times\left(10^{-}\right.\right. \\
& \left.\left.{ }^{5}\right)\left(10^{3}\right)\right) \\
& =999,5838 \mathrm{~kg} / \mathrm{m}^{3} \\
& \boldsymbol{T}_{\boldsymbol{H}}=60^{\circ} \mathrm{C}, \\
& \rho(60)=999,96124+(0,01998(60))- \\
& \left(0,00593\left(60^{2}\right)\right)+\left(1,57658 \times\left(10^{-}\right.\right. \\
& \left.\left.{ }^{5}\right)\left(60^{3}\right)\right) \\
& =983,2175 \mathrm{~kg} / \mathrm{m}^{3}
\end{aligned}
$$

Densitas air adalah hasil bagi dua antara penjumlahan densitas air pada temperatur cooler dan pada temperatur Sehingga diperoleh nilai densitas sebagai berikut: 


$$
\rho_{W}=\frac{\rho(10)+\rho(60)}{2}=991,4006 \mathrm{~kg} / \mathrm{m}^{3}
$$

Untuk temperatur yang lain dapat dilakukan perhitungan yang sama seperti diatas.

Setelah semua data telah terpenuhi, selanjutnya dilakukan perhitungan laju aliran fluida. Contoh perhitungannya adalah sebagai berikut.

$$
\begin{array}{ll}
T_{C} & =10^{\circ} \mathrm{C} \\
T_{H} & =60^{\circ} \mathrm{C} \\
L & =19 \mathrm{~m} \\
K & =2,65 \\
H & =3,5 \mathrm{~m} \\
D & =0,0254 \mathrm{~m} \\
g & =10 \mathrm{~m} / \mathrm{s}^{2} \\
\mu & =0,000897 \mathrm{~Pa} . \mathrm{s} \\
\rho(10) & =999,5838 \mathrm{~kg} / \mathrm{m}^{3} \\
\rho(60) & =983,2175 \mathrm{~kg} / \mathrm{m}^{3} \\
\rho_{W} & =991,4006 \mathrm{~kg} / \mathrm{m}^{3}
\end{array}
$$

Dari data-data tersebut dapat tentukan nilai laju aliran fluida dengan persamaan (1) sebagai berikut

$$
v=\frac{-64 \mu L+\sqrt{(64 \mu L)^{2}+8 g H K \rho_{W} D^{4}\left(\rho_{C}-\rho_{H}\right)}}{2 K \rho_{W} D^{2}}
$$$$
v=0,6894 \mathrm{~m} / \mathrm{s}
$$

Berdasarkan perhitungan di atas dengan menggunakan program Matlab diperoleh data estimasi laju aliran sirkulasi alam, seperti yang ditampilkan pada Tabel 2, Tabel 3, Tabel 4, Tabel 5 dan Tabel 6, secara berturut-turut untuk setting temperatur cooler dari $10^{\circ} \mathrm{C}, 20^{\circ} \mathrm{C}, 30^{\circ} \mathrm{C}, 40^{\circ} \mathrm{C}$ dan $50^{\circ} \mathrm{C}$ pada setiap perubahan temperature di heater dari $60^{\circ} \mathrm{C}$ hingga $100^{\circ} \mathrm{C}$.
Tabel 2. Estimasi laju aliran fluida pada temperatur cooler $10^{\circ} \mathrm{C}$

\begin{tabular}{|c|c|c|c|c|}
\hline $\begin{array}{c}T_{C} \\
\left({ }^{\circ} \mathrm{C}\right)\end{array}$ & $\begin{array}{c}T_{H} \\
\left({ }^{\circ} \mathrm{C}\right)\end{array}$ & $\begin{array}{c}\mu\left(10^{-3}\right. \\
\text { Pa.s })\end{array}$ & $\begin{array}{c}\rho_{W} \\
\left(\mathrm{~kg} / \mathrm{m}^{3}\right)\end{array}$ & $v(\mathrm{~m} / \mathrm{s})$ \\
\hline 10 & 60 & 0,8965 & 991,4006 & 0,6894 \\
\hline 10 & 70 & 0,8746 & 988,6472 & 0,7844 \\
\hline 10 & 80 & 0,8563 & 985,6318 & 0,8775 \\
\hline 10 & 90 & 0,8337 & 982,4018 & 0,9654 \\
\hline 10 & 100 & 0,7989 & 979,0044 & 1,0456 \\
\hline
\end{tabular}

Tabel 3. Estimasi laju aliran fluida pada temperatur cooler $20^{\circ} \mathrm{C}$

\begin{tabular}{|c|c|c|c|c|}
\hline $\begin{array}{c}T_{C} \\
\left({ }^{\circ} \mathrm{C}\right)\end{array}$ & $\begin{array}{c}T_{H} \\
\left({ }^{\circ} \mathrm{C}\right)\end{array}$ & $\begin{array}{c}\mu\left(10^{-3}\right. \\
\text { Pa.s })\end{array}$ & $\begin{array}{c}\rho_{W} \\
\left(\mathrm{~kg} / \mathrm{m}^{3}\right)\end{array}$ & $v(\mathrm{~m} / \mathrm{s})$ \\
\hline 20 & 60 & 0,7373 & 990,6662 & 0,6029 \\
\hline 20 & 70 & 0,7153 & 987,9127 & 0,7051 \\
\hline 20 & 80 & 0,6970 & 984,8973 & 0,8037 \\
\hline 20 & 90 & 0,6744 & 981,6673 & 0,8969 \\
\hline 20 & 100 & 0,6397 & 978,2700 & 0,9836 \\
\hline
\end{tabular}

Tabel 4. Estimasi laju aliran fluida pada temperatur cooler $30^{\circ} \mathrm{C}$

\begin{tabular}{|c|c|c|c|c|}
\hline $\begin{array}{c}T_{C} \\
\left({ }^{\circ} \mathrm{C}\right)\end{array}$ & $\begin{array}{c}T_{H} \\
\left({ }^{\circ} \mathrm{C}\right)\end{array}$ & $\begin{array}{c}\mu\left(10^{-3}\right. \\
\text { Pa.s })\end{array}$ & $\begin{array}{c}\rho_{W} \\
\left(\mathrm{~kg} / \mathrm{m}^{3}\right)\end{array}$ & $v(\mathrm{~m} / \mathrm{s})$ \\
\hline 30 & 60 & 0,6213 & 989,4334 & 0,5215 \\
\hline 30 & 70 & 0,5993 & 986,6799 & 0,6344 \\
\hline 30 & 80 & 0,5811 & 983,6645 & 0,7407 \\
\hline 30 & 90 & 0,5585 & 980,4345 & 0,8404 \\
\hline 30 & 100 & 0,5237 & 977,0372 & 0,9340 \\
\hline
\end{tabular}

Tabel 5. Estimasi laju aliran fluida pada temperatur cooler $40^{\circ} \mathrm{C}$

\begin{tabular}{|c|c|c|c|c|}
\hline $\begin{array}{c}T_{C} \\
\left({ }^{\circ} \mathrm{C}\right)\end{array}$ & $\begin{array}{c}T_{H} \\
\left({ }^{\circ} \mathrm{C}\right)\end{array}$ & $\begin{array}{c}\mu\left(10^{-3}\right. \\
\text { Pa.s })\end{array}$ & $\begin{array}{c}\rho_{W} \\
\left(\mathrm{~kg} / \mathrm{m}^{3}\right)\end{array}$ & $v(\mathrm{~m} / \mathrm{s})$ \\
\hline 40 & 60 & 0,5408 & 987,7495 & 0,4257 \\
\hline 40 & 70 & 0,5188 & 984,9960 & 0,5560 \\
\hline 40 & 80 & 0,5005 & 981,9806 & 0,6735 \\
\hline 40 & 90 & 0,4779 & 978,7506 & 0,7819 \\
\hline 40 & 100 & 0,4432 & 975,3532 & 0,8831 \\
\hline
\end{tabular}

Tabel 6. Estimasi laju aliran fluida pada temperatur cooler $50^{\circ} \mathrm{C}$ 


\begin{tabular}{|c|c|c|c|c|}
\hline $\begin{array}{c}T_{C} \\
\left({ }^{\circ} \mathrm{C}\right)\end{array}$ & $\begin{array}{c}T_{H} \\
\left({ }^{\circ} \mathrm{C}\right)\end{array}$ & $\begin{array}{c}\mu\left(10^{-3}\right. \\
\text { Pa.s })\end{array}$ & $\begin{array}{c}\rho_{W} \\
\left(\mathrm{~kg} / \mathrm{m}^{3}\right)\end{array}$ & $v(\mathrm{~m} / \mathrm{s})$ \\
\hline 50 & 60 & 0,4877 & 985,6617 & 0,2903 \\
\hline 50 & 70 & 0,4657 & 982,9082 & 0,4555 \\
\hline 50 & 80 & 0,4474 & 979,8928 & 0,5914 \\
\hline 50 & 90 & 0,4248 & 976,6628 & 0,7120 \\
\hline 50 & 100 & 0,3901 & 973,2655 & 0,8226 \\
\hline
\end{tabular}

Berdasarkan hasil perhitungan estimasi laju aliran sirkulasi alam yang disajikan pada Tabel 2, Tabel 3, Tabel 4, Tabel 5 dan Tabel 6, terlihat bahwa ketika beda temperatur antara $\mathrm{BCH}$ dan WTC semakin besar, maka laju aliran sirkulasi alam yang terjadi semakin cepat. Estimasi laju aliran sirkulasi alam dipresentasikan dalam grafik seperti pada Gambar 9.a dan Gambar 9.b.

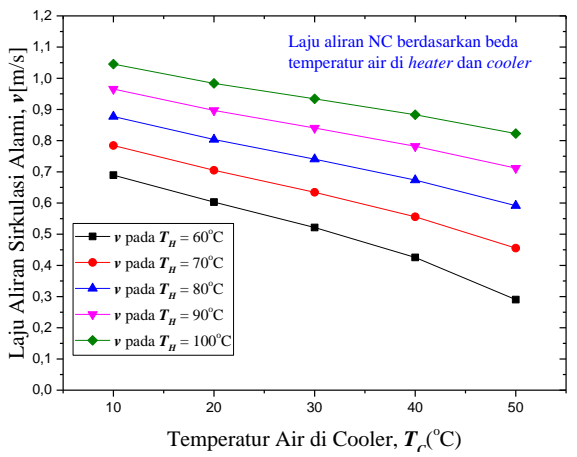

(a)

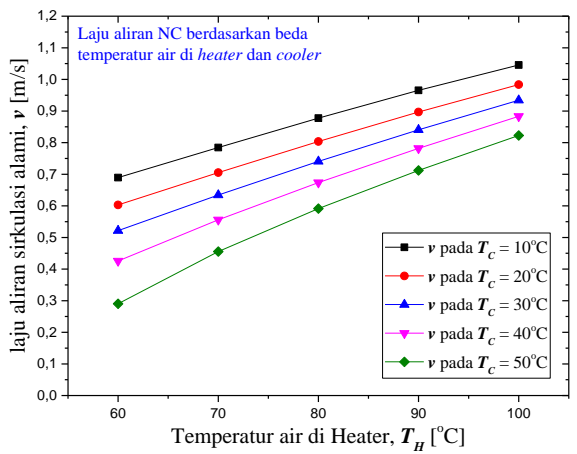

(b)

Gambar 9 Grafik estimasi laju aliran sirkulasi alam terhadap temperatur

(a)WTC

(b) $\mathrm{BCH}$

Grafik pada Gambar 9.a menunjukkan bahwa adanya laju aliran yang terjadi pada untai FASSIP-01 yang terjadi akibat perbedaan temperatur antara $\mathrm{BCH}$ dan WTC. Terlihat pada gambar 9 bahwa semakin besar perbedaan temperatur anatara BCH dan WTC, maka akan semakin besar pula laju aliran air pada untai FASSIP-01. Ketika perbedaan temperatur $\mathrm{BCH}$ dan WTC $10^{\circ} \mathrm{C}$, laju aliran bernilai paling kecil yaitu $0,2903 \mathrm{~m} / \mathrm{s}$ (Tabel 2) , sedangkan ketika perbedaan temperatur $\mathrm{BCH}$ dan WTC $90^{\circ} \mathrm{C}$, laju aliran bernilai paling besar yaitu $1,0456 \mathrm{~m} / \mathrm{s}$ (Tabel 6).

Saat air mengalir pada pipa yang melewati Blanket Ceramic Heater (BHC), air akan dipanaskan (secara radiasi) sampai temperatur tertentu, sehingga densitas air akan menjadi lebih kecil dari keadaan normal yang menyebabkan adanya gaya bouyancy (gaya apung). Air dengan densitas lebih kecil akan naik ke atas akibat gaya apung sehingga memasuki Water Cooling Tank (WTC). Ketika melalui WTC, kalor yang dimiliki air akan diserap sehingga temperatur air yang melewati WTC menjadi lebih rendah dan densitasnya menjadi lebih besar, pada keadaan ini air dipengaruhi gaya gravitasi dan turun ke bawah sehingga masuk kembali ke $\mathrm{BCH}$ dan mengalam 
proses pemanasan seperti proses sebelumnya.

\section{DAFTAR PUSTAKA}

Kondisi yang diuraikan di atas dapat dijelaskan bahwa, moleku air akan merenggang pada temperatur tinggi, dan akan lebih rapat pada temperatur rendah. Perbedaan temperatur menyebabkan interaksi antar molekul renggang dan molekul rapat, apabila beda temperatur besar maka interaksi antara molekul renggang dan molekul rapat terjadi sangat cepat dan hal tersebut yang mengakibatkan adanya laju aliran. Semakin besar beda temperatur maka laju aliran fluida akan semakin cepat pula, demikian sebaliknya jika beda temperatur kecil maka laju alirannya juga akan kecil. Sehingga utuk mengestimasi hasil perhitungan, digunakan fitting dengan persamaan polynomial orde-3 untuk meminimalisir deviasi errornya hingga di bawah $1 \%$ (berbasis R square).

\section{KESIMPULAN}

Estimasi nilai laju aliran sirkulasi alam fluida pada desain Untai FASSIP-01 terbesar yakni $1,0456 \mathrm{~m} / \mathrm{s}$ yang terjadi pada $\boldsymbol{T}_{\boldsymbol{C}}=10^{\circ} \mathrm{C}$ dan $\boldsymbol{T}_{\boldsymbol{H}}=100^{\circ} \mathrm{C}$ dan tekecil yakni $0,2903 \mathrm{~m} / \mathrm{s}$ yang terjadi pada $\boldsymbol{T}_{\boldsymbol{C}}=50^{\circ} \mathrm{C}$ dan $\boldsymbol{T}_{\boldsymbol{H}}=60^{\circ} \mathrm{C}$. Kondisi tersebut jelas menunjukkan bahwa beda temperature akan memperbesar beda kerapatan fluida pada masing-masing bagian (heater dan cooler) sehingga gaya-gaya yang bekerja semakin besar memicu laju aliran sirkulasi alam.

1. DEIL, SISKA AMELIE F. 2015. 5 Treagedi Nuklir Terparah diambil dari

https://www.liputan6.com/news/read/ 2234651/5-tragedi-nuklir-terparah, diakses pada tanggal 19 Juli 2018, pukul 15.46 WIB

2. YORAM, ZVIRIN. 1981. A Review of Natural Circulation Loop in Pressureized Water Reactors and Other System. USA : Palo Alto.

3. SETYAWAN, DEDY, dkk. 2009. Perancangan Model Sistem Pendingin pada Sungkup AP1000. Bandung : Prosiding Seminar Nasional Sains dan Teknologi Nuklir.

4. WANG, DONGQING, dkk. 2016. Potential Application of a Thermoelectric Generator in Passive Cooling System of Nuclear Power Plants. Journal of ELECTRONIC MATERIALS, Vol. 46, No. 5, 2017

5. JUARSA, M, dkk. 2014. Preliminary Study On Mass Flow Rate In Passive Coolig Experimental Simulation During Transient Using Nc-Queen Apparatus. Tangerang, National Nuclear Energy Agency. Atom Indonesia Vol 40 No 3, 141-147

6. MAHRAN NOUFAL, dkk. 2015. Analisis Unjuk Kerja Pemanas dan Vol.23 No.2 November 2019 
Pendingin di Untai Fasilitas

Simulasi Sistem Pasif. Vol.19. Sigma

Epsilon, ISSN 0853-9103.

7. Anonymous. Natural Circulation diambil dari https://www.nuclearpower. net/ nuclear-engineering/ heat transfer/convection-convectiveheattransfer/natura 1-convection-freeconvection/natural circulation/, diakses pada tanggal 30 Juli 2018, pukul 13.33 WIB

8. Anonymous. Water - Dynamic and Kinematic Viscosity diambil dari https://www.engineeringtoolbox.com /water-dynamic-kinematic viscosityd_596. html, diakses pada tanggal 30 Juli 2018, pukul 13.40 WIB

9. A. CRABTREE AND M. SIMANTOV.1993. Thermophysical Properties of Saturated Light and Heavy Water for Advanced Neutron Source Applications. Oak Ridge National Lab., Tn (United States).

10. Anonymous. Water - Density, Specific Weight and Thermal Expantion Coefficient diambil dari https://www.engineering toolbox.com/ water-density-specificweight-d_595. html, diakses pada tanggal 30 Juli 2018, pukul 13.40 WIB 